DOI: https://doi.org/10.24127/ajpm.v10i1.3464

\title{
ANALISIS PEMAHAMAN KONSEP SISWA PADA MATERI LOGARITMA DITINJAU DARI KEMAMPUAN AWAL MATEMATIKA
}

\author{
Eka Aprilia $^{1}$, Triyanto $^{2}$, Diari Indriati ${ }^{3}$ \\ ${ }^{1,2,3}$ Universitas Sebelas Maret, Surakarta, Indonesia \\ E-mail: $\quad$ ekaapriliapur@gmail.com $^{1)}$ \\ triyanto@fkip.uns.ac.id ${ }^{2}$ \\ diari_indri@yahoo.co.id ${ }^{3 *}$
}

Received 06 January 2021; Received in revised form 06 March 2021; Accepted 12 April 2021

\begin{abstract}
Abstrak
Tujuan penelitian ini adalah untuk menganalisis kemampuan pemahaman konsep matematis siswa ditinjau dari kemampuan awal matematika. Penelitian ini adalah penelitian deskriftif eksploratif dengan pendekatan kualitatif. Penelitian ini dilaksanakan di SMA Muhammadiyah 5 Yogyakarta Tahun Ajaran 2020/2021 pada kelas X. Subjek penelitian ini terdiri dari dua siswa dengan kemampuan awal tinggi, dua siswa kemampuan awal sedang dan dua siswa kemampuan awal rendah. Sumber data penelitian ini adalah hasil tes dan hasil wawancara. Fokus penelitian ini adalah untuk mendeskripsikan pemahaman siswa tentang logaritma berdasarkan kemampuan awal yang dimiliki. Hasil penelitian ini menunjukkan bahwa pemahaman konsep siswa dipengaruhi oleh kemampuan awal yang mereka miliki. Sehingga siswa dengan kemamapuan awal tinggi mendominasi lebih menguasai indikator pemahaman konsep dibandingkan dengan siswa berkemampuan awal sedang atau rendah.
\end{abstract}

Kata kunci : Analisis; kemampuan awal; pemahaman konsep

\begin{abstract}
The purpose of this research is to analyze the students' understanding of mathematical concepts in terms of their initial mathematical abilities. This research is descriptive explorative research with a qualitative approach. This research wa conducted at SMA Muhammadiyah 5 Yogyakarta academic year 2020/2021 in class $X$. the subject of this study consisted of two students with high initial abilities, moderate initial ability, and low initial ability. Sources of data in this study were obtained from test resukt and interview result. The focus of this research is to describe students' understanding of logarithms based or their initial abilities. The results of this study indicate that students' understanding of concepts is influenced by the initial abilities they have. So that students with high initial abilities dominate more in mastering the indicators of concept understanding than students with moderate or low initial abilities.
\end{abstract}

Keywords : Analysis; conceptual understanding; initial ability

This is an open access article under the Creative Commons Attribution 4.0 International License

\section{PENDAHULUAN}

Matematika Salah satu ilmu pengetahuan yang berperan penting dalam kehidupan (Gunawan, 2019), matematika merupakan salah satu mata pelajaran yang berfungsi mengembangkan kemampuan menghitung, mengukur dan menggunakan rumus matematika yang dapat diaplikasikan dalam kehidupan sehari-hari (Kartika, 2018).
Tujuan utama mempelajari matematika yaitu untuk menyelesaikan suatu masalah yang berkenaan dengan perhitungan maupun penerapan ilmu itu dengan pengaplikasian konsepnya (Unaenah et al., 2017). Pada kenyataannya tujuan tersebut belum terpenuhi sepenuhnya, bagi siswa untuk memahami konsep matematika merupakan hal yang tidak mudah (Nikmah, 2016). Kesulitan memahami konsep 
bukan hanya dikarenakan materi tetapi kurang tepatnya model pembelajaran yang digunakan (Sari et al., 2017).

Menurut penelitian (Achir et al., 2017) Kesalahan dalam memahami konsep yang dialami siswa disebabkan karena siswa menganggap soal sulit dan kurang antusias untuk memahami soal, sehingga siswa bingung untuk menyelesaikan soal tersebut. Sedangkan menurut hasil penelitian (Kartika, 2018) pemahamn konsep matematika siswa masih rendah, seharusnya pemahamn konsep yang baik dapat dicapai dengan metode pembelajaran yang berbagai macam dan tidak monoton.

Salah satu materi yang harus dipahami konsepnya didalam pembelajaran matematika yaitu logaritma, memahami konsep dengan baik akan mempermudah siswa dalam menyelesaikan soal. (Ong, 2020) mengatakan dalam penelitiannya bahwa salah satu factor yang siswa tidak dapat menyelesaikan soal logaritma yaitu rendahnya pemahaman konsep yang dimiliki siswa. Hal ini juga sejalan dengan penelitian yang dilakukan (Darjiani et al., 2015)menyatakn ratarata siswa yang melakukan kesalahan dalam pengerjaan soal adalah 49,25\%, dengan kesalahan yang paling sering adalah kesalahan dalam pemahaman konsep yaitu $8,65 \%$, kesalahan dalam pemecahan masalah 7,26 persen, kesalahan dalam 2 aspek sekaligus yaitu konsep dan keterampilan berhitung 4,93\%, kesalahan dalam pemecahan masalah dan keterampilan berhitung 4,70\%, kesalahan dalam keterampilan berhitung yaitu 14,23\%, kesalahan dalam pemahaman konsep dan pemecahan masalah $0,90 \%$, dan kesalahan dalam tiga aspek yaitu pemahaman konsep, keterampilan berhitung, dan pemecahan masalah adalah $8,37 \%$. Sehingga kesalahan pemahaman konsep yang paling sering terjadi dalam pembelajaran.

Selain pemahaman konsep, kemampuan awal juga perlu dipertimbangkan dalam proses pembelajaran, konsep-konsep yang sudah ada dalam diri siswa merupakan kemapuan awal (Irawati, 2014). Kemampuan awal berpengaruh dalam proses pembentukan pengetahuan siswa sehingga perlu diperhatikan agar proses pembentukan pengetahuan dalam diri siswa berjalan dengan baik. Hal ini sejalan dengan (Akramunnisa \& Sulestry 2016) yang mengatakan konsep matematika yang satu dan yang lainnya berkolerasi sehingga membentuk suatu konsep baru yang kompleks dan siswa tidak dapat menyelesaikan masalah mungkin karna tingkat kemampuan awalnya yang masih kurang. Menurut (Astuti, 2015) kemampuan awal matematika merupakan kemampuan awal atau prasyarat awal untuk mengetahui adanya perubahan. Kemampuan awal berkenaan dengan kecerdasanyang dimiliki siswa. Kecerdasan yang siswa beragam ada yang pandai, sedang-sedang saja dan lemah. Berdasarkan uraian tersebut, maka perlu dilakukan penelitian untuk menganalisis pemahaman konsep siswa pada materi logaritma ditinjau dari kemampuan awal siswa di SMA Muhamadiyah 5 Yogyakarta.

\section{METODE PENELITIAN}

Penelitian ini adalah penelitian deskriftif-eksploratif dengan pendekatan kualitatif yang bertujuan menganalisis pemahaman konsep siswa kelas X pada materi logaritma yang berpedoman pada terpenuhi atau tidaknya indikatorindikator pemahaman konsep. Teknik pengumpulan data yang digunakan yaitu simple random sampling dari 3 sekolah di kecamatan Ngampilan, Yogyakarta. Subjek penelitian ini adalah seluruh 
DOI: https://doi.org/10.24127/ajpm.v10i1.3464

siswa kelas $X$ IPA di SMA Muhammadiyah 5 Yogyakarta, yang bertempatan di Kompleks Perguruan Muhammadiyah, J1. Purwodiningratan NG I No.902 A, Ngampilan, Kota Yogyakarta, Daerah Istimewa Yogyakarta. Dengan jumlah subjek penelitian ini terdiri dari dua siswa dengan kemampuan awal tinggi, dua siswa kemampuan awal sedang dan dua siswa kemampuan awal rendah. Waktu pelaksanaan penelitian ini pada bulan Oktober-Desember 2020.

Instrumen dalam penelitian ini peneliti sendiri sebagai instrument utama dipandu dengan tes kemampuan matematika awal, soal pemahaman konsep logaritma dan pedoman wawancara. Langkah pengumpulan data yaitu mengelompokkan subjek penelitian berdasarkan kategori kemampuan awal tinggi, sedang dan rendah serta memenuhi berdasarkan kriteria yang telah ditentukan. Kemudian melakukan pengambilan data pemahaman konsep matematika siswa dengan cara memberikan soal pemahaman konsep matematika kepada subjek. Adapun pengelompokkan siswa dalam tiga kategori kemampuan awal matematika dilakukan berdasarkan kriteria penilaian menurut (Sujalmo et al., 2012) pada Tabel 1.

Tabel 1. kategori kemampuan awal matematika siswa

\begin{tabular}{ccc}
\hline No & kategori & Skor \\
\hline 1 & Tinggi & Skor $\geq 80$ \\
2 & Sedang & $65<$ Skor $<80$ \\
3 & Rendah & Skor $\leq 80$ \\
\hline
\end{tabular}

Berdasarkan hasil kemampuan awal pada Tabel 2 Subjek yang akan diambil terdiri dari 3 kelompok yaitu 2 orang siswa yang memiliki kemampuan awal tinggi, 2 siswa yang berkemampuan awal sedang, dan 2 orang siswa yang berkemampuan awal rendah.

Tabel 2. hasil persentase tingkat kemampuan awal siswa Muhammadiyah 5 yogyakarta

\begin{tabular}{ccc}
\hline No & kategori & Persentase \\
\hline 1 & Tinggi & $16 \%$ \\
2 & Sedang & $20 \%$ \\
3 & Rendah & $36 \%$ \\
\hline
\end{tabular}

Teknik analisis data dilakukan pada setiap menyelesaikan soal yang kemudian dianalisis menurut 3 indikator pemahaman konsep, yaitu (1) mengklarifikasi objek menurut sifat-sifat tertentu sesuai dengan konsepnya, (2) mengembangkan syarat perlu dan syarat cukup, dan (3) menggunakan, memanfaatkan dan memilih prosedur atau operasi tertentu. Langkah selanjutnya adalah penarikan kesimpulan dan dan verifikasi data yang diperoleh akan menjadi temuan baru berupa pemahaman konsep matematika dari masing-masing subjek penelitian.

\section{HASIL DAN PEMBAHASAN}

Data dalam penelitian ini adalah data tes pemahaman konsep matematika dan wawancara. Data tes dan wawancara pemahaman konsep matematika siswa pada kategori kemampuan awal tinggi, sedang dan rendah disajikan sebagai berikut:

Tabel 3. Pemahaman konsep pada materi logaritma subjek berkemampuan awal matematika tinggi

\begin{tabular}{|c|c|c|}
\hline \multirow{2}{*}{$\begin{array}{c}\text { No } \\
\text { soal }\end{array}$} & \multicolumn{2}{|c|}{ Skor tahap pemahaman konsep } \\
\hline & ST-01 & ST-02 \\
\hline 1 & 3 & 2 \\
\hline 2 & 3 & 3 \\
\hline 3 & 4 & 3 \\
\hline
\end{tabular}

operasi campuran logaritma, ST-01 mengerjakan dan dapat menggunakan 
atau memilih prosedur operasi tetapi belum tepat, sedangkan ST-02 dapat menggunakan atau memilih prosedur operasi tetapi masih ada banyak kesalahan. Pada soal kedua tentang pemisalan logaritma ST-01 dan ST-02 mendapat skor 3 sampai ditahap dapat menggunakan, memanfaatkan, dan memilih prosedur atau operasi tetapi masih belum tepat. Pada soal ketiga mengenai persamaan logaritma ST-01 menyelesaikan soal dengan baik, sampai dimengaplikasikan rumus sesuai prosedur dalam menyelesaikan soal pemecahan masalah dengan tepat, sedangkan ST-02 menyelesaikan soal.

Table 4. Pemahaman konsep pada materi logaritma subjek berkemampuan awal matematika sedang

\begin{tabular}{|c|c|c|}
\hline \multirow{2}{*}{$\begin{array}{c}\text { No } \\
\text { soal }\end{array}$} & \multicolumn{2}{|c|}{ Skor tahap pemahaman konsep } \\
\hline & SS-01 & SS-02 \\
\hline 1 & 4 & 2 \\
\hline 2 & 3 & 2 \\
\hline 3 & 3 & 2 \\
\hline
\end{tabular}

operasi campuran logaritma, SS-01 mengerjakan dengan baik sampai tahap dapat menggunakan atau memilih prosedur operasi dengan tepat, sedangkan SS-02 dapat menggunakan atau memilih prosedur atau operasi tetapi masih ada banyak kesalahan. Pada soal kedua tentang pemisalan logaritma SS01 sampai ditahap dapat menggunakan, memanfaatkan, dan memilih prosedur atau operasi tetapi masih belum tepat, sedangkan SS-02 dapat menggunakan, memanfaatkan, atau memilih prosedur atau operasi tetapi masih ada banyak kesalahan Pada soal ketiga mengenai persamaan logaritma SS-01 menyelesaikan soal sampai mengaplikasikan rumus sesuai prosedur dalam menyelesaikan soal tetapi belum tepat, sedangkan SS-02 menyelesaikan soal sampai dengan mengaplikasikan rumus sesuai prosedur dalam menyelesaikan soal pemecahan masalah tetapi masih banyak kesalahan.

Table 5. Pemahaman konsep pada materi logaritma subjek berkemampuan awal matematika rendah

\begin{tabular}{|c|c|c|}
\hline \multirow{2}{*}{$\begin{array}{c}\text { No } \\
\text { soal }\end{array}$} & \multicolumn{2}{|c|}{ Skor tahap pemahaman konsep } \\
\hline & SR-01 & SR-02 \\
\hline 1 & 2 & 2 \\
\hline 2 & 4 & 1 \\
\hline 3 & 1 & 1 \\
\hline
\end{tabular}

operasi campuran logaritma, SR-01dan SR-02 dapat menggunakan atau memilih prosedur atau operasi yang digunakan tetapi masih banyak kesalahan. Pada soal kedua tentang pemisalan logaritma SR01 menyelesaikan soal dengan baik sampai ditahap dapat menggunakan, memanfaatkan, dan memilih prosedur atau operasi dengan tepat, sedangkan SR-02 tidak dapat menggunakan, memanfaatkan, atau memilih prosedur atau operasi. Pada soal ketiga mengenai persamaan logaritma SR-01 dan SR-02 tidak dapat mengaplikasikan rumus sesuai prosedur dalam menyelesaikan soal.

Berdasarkan temuan penelitian yang telah peneliti jabarkan diatas dapat diketahui bahwasanya penelitian mengenai analisis pemahaman konsep ditinjau dari kemampuan awal siswa kelas X di SMA Muhammadiyah 5 Yogyakarta, Semester Ganjil Tahun Pelajaran 2020/2021, adapun penjabaran dari penelitian ini adalah sebagai berikut: kemampuan awal yang dimiliki siswa pasti akan mempengaruhi pemahaman konsep dalam memecahkan masalah. Terlihat jelas dari data yang telah peneliti peroleh, bahwa subjek dengan kemampuan awal matematika tinggi tidak jauh berbeda dengan siswa yang meiliki kemampuan awal rendah dalam 
pemahaman konsep, namun lebih unggul dari siswa dengan kemampuan awal rendah. dalam menyelesaikan masalah. Hal tersebut sependapat (Hikmah et al., 2016) (2016) yang menyatakan bahwa siswa berpemahaman konsep dengan minat tinggi, dapat menjelaskan konsep, keterkaitan antar konsep, mengedepankan aplikasi konsep, dan yakin terhadap konsepnya. (Yufentya et al., 2019) mengatakan dalam penelitiannya bahwa siswa berkemampuan tinggi telah memiliki kemampuan pemahaman konsep yang baik sebab telah mencapai lebih dari $50 \%$ untuk setiap indikator. Sementara untuk siswa berkemampuan sedang dan rendah, memiliki pemahaman konsep yang kurang baik sebab hasil yang diperoleh kurang dari $50 \%$ untuk masing-masing indikator. Penelitian (Fajar et al., 2019) mengatakan kemampuan pemahaman konsep matematis siswa sebagian besar berada pada kategori rendah, maka diperlukan pengajaran yang lebih mendalam oleh guru yang berkaitan dengan pemahaman konsep matematika siswa pada pembelajaran di kelas. Penelitian lain mengatkan jika kemampuan awal matematika baik maka kemampuan pemahaman konsep matematis juga baik, yang berarti kemampuan awal mempengaruhi kemampuan pemahaman konsep (Utami \& Anitra, 2019). Penelitian (Yulianah et al., 2020) mengatakan bahwa pemahaman konsep matematika akan sangat terbantu jika menggunakan media pembelajaran sebagai sarana tercapainya tujuan pendidikan. Sebab secara tidak langsung guru melatih siswa hanya untuk keterampilan berhitung dan siswa memiliki kecendrungan untuk menghafal rumus yang ada. Mampu menyelesaikan atau memecahkan masalah matematis memang merupakan salah tujuan pembelajaran matematika, namun hal itu dapat dicapai ketika siswa memiliki pemahaman konsep yang baik. Dari pembahasan diatas dapat disimpulakan bahwa hasil dari penelitian ini yaitu pemahaman konsep siswa dipengaruhi oleh kemampuan awal matematis dan metode yang digunakan guru dalam pembelajaran, karna dengan pembelajaran yang menarik dan modifikasi akan lebih baik bagi siswa dalam mencapai kemampuan pemahaman konsep guna tercapainya tujuan Pendidikan.

\section{KESIMPULAN DAN SARAN}

Berdasarkan teori dan didukung oleh dengan hasil analisis dan pengolahan data serta mengacu pada perumusan masalah yang telah diuraikan, maka dapat disimpulkan bahwa pada penelitian ini siswa yang memiliki kemampuan awal yang tinggi dan sedang menguasai indikator pemahaman konsep matematika yang sama-sama baik, sedangkan siswa yang memiliki kemampuan awal rendah belum mampu memahami konsep dengan baik.

Saran penelitian ini yaitu sebaiknya guru dapat melakukan inovasi dalam pembelajaran matematika seperti menggunakan model, pendekatan, atau media pembelajaran yang terbaru dan juga inovatif. Adapun saran bagi peneliti lain, hendaknya penelitian ini dapat dijadikan acuan bagi penelitian selanjutnya agar dapat berkontribusi dalam upaya meningkatkan mutu dan kualitas pendidikan.

\section{DAFTAR PUSTAKA}

Achir, Y. S., Usodo, B., \& Retiawan, R. (2017). Analisis Kemampuan Komunikasi Matematis Siswa Dalam Pemecahan Masalah Matematika Pada Materi Sistem Persamaan Linear Dua Variabel (Spldv) Ditinjau Dari Gaya Kognitif. Paedagogia, 20(1), 78. 
DOI: https://doi.org/10.24127/ajpm.v10i1.3464

https://doi.org/10.20961/paedagogia .v20i1.16600

Akramunnisa, \& Sulestry, A. I. (2016). Analisis Kemampuan Menyelesaikan Masalah Matematika Ditinjau Dari Kemampuan Awal Tinggi Dan Gaya Kognitif Field Independent ( Fi ). Pedagogy: Jurnal Pendidikan Matematika, 1(2), 46-56. http://journal.uncp.ac.id/index.php/ Pedagogy

Astuti, S. P. (2015). Pengaruh Kemampuan Awal Dan Minat Belajar. Jurnal Formatif, 5(1), 68 75.

http://journal.lppmunindra.ac.id/ind ex.php/Formatif/article/viewFile/16 $7 / 160$

Darjiani, N. N. Y., Meter, I. G., \& Negara, I. G. A. O. (2015). Analisis Kesulitan-Kesulitan Belajar Matematika Siswa Kelas V Dalam Implementasi Kurikulum 2013 di SD Piloting Se-Kabupaten Gianyar Tahun Pelajaran 2014 / 2015. EJournal PGSD Universitas Pendidikan Ganesha, 3(1), 1-11. https://ejournal.undiksha.ac.id/inde x.php/JJPGSD/article/view/5070

Fajar, A. P., Kodirun, K., Suhar, S., \& Arapu, L. (2019). Analisis Kemampuan Pemahaman Konsep Matematis Siswa Kelas VIII SMP Negeri 17 Kendari. Jurnal Pendidikan Matematika, 9(2), 229. https://doi.org/10.36709/jpm.v9i2.5 872

Gunawan, G. (2019). Analisis Kemampuan Pemecahan Masalah Matematis Siswa Menggunakan Model Pembelajaran Team Games Tournament Sma Muhammadiyah 1 Purwokerto. AKSIOMA: Jurnal
Program Studi Pendidikan Matematika, 8(1), 83-90. https://doi.org/10.24127/ajpm.v8i1. 1731

Irawati, R. K. (2014). Pengaruh Model Problem Solving dan Problem Posing serta Kemampuan Awal terhadap Hasil Belajar Siswa. Jurnal Pendidikan Sains, 2(4), 184192.

https://doi.org/10.17977/jps.v2i4.45 34

Kartika, Y. (2018). Analisis Kemampuan Pemahaman Konsep Matematis Peserta Didik Kelas Vii Smp Pada Materi Bentuk Aljabar. Jurnal Pendidikan Tambusai, 2(4), 777785.

Nikmah, N. S. \& M. (2016). Penggunaan peta konsep dalam penilaian pemahaman konsep lingkaran. Knpmp I, 11-22.

Sari, W. P., Suyanto, E., \& Suana, W. (2017). Analisis Pemahaman Konsep Vektor pada Siswa Sekolah Menengah Atas. Jurnal Ilmiah Pendidikan Fisika Al-Biruni, 6(2), 159.

https://doi.org/10.24042/jipfalbiruni .v6i2.1743

Solaikah, \& septi, N. D. (2013). Identifikasi Kemampuan Siswa Dalam Menyelesaikan Soal. Jurnal Pendidikan Matematika STKIP PGRI Sidoarjo, 1(1), 97-106.

Unaenah, E., Syarif, M \& Sumantri (2017). Analisis Pemahaman Konsep Matematis Siswa Kelas 5 Sekolah Dasar Pada Materi Pecahan Jurnal basicedu. Jurnal Basicedu, 3(1), 106-119 
DOI: https://doi.org/10.24127/ajpm.v10i1.3464

Utami, C., \& Anitra, R. (2019). Kemampuan Pemahaman Konsep Matematis Mahasiswa Ditinjau dari Kemampuan Awal Pada Mata Kuliah Matematika SD. Jurnal Keilmuan Dan Kependidikan Dasar, 11(02), 103-110.

Wahyuni, A. (2020). Analisis Kesalahan Siswa dalam Menyelesaikan Soal Aritmatika Sosial. Jurnal Pendidikan Matematika, 11(1), 67. https://doi.org/10.36709/jpm.v11i1. 10022
Yufentya, W. E., Roza, Y., \& Maimunah, M. (2019). Analisis Kemampuan Pemahaman Konsep Siswa Kelas VIII SMP pada Materi Lingkaran. Desimal: Jurnal Matematika, 2(3), 197-202. https://doi.org/10.24042/djm.v2i3.4 175

Yulianah, Lia; Ni'mah, Khomsatun; Veni Rahayu, D. (2020). Analisis Kemampuan Pemahaman Konsep Matematika Siswa Berbantuan Media Schoology. Jurnal Delivat, 7, 39-45. 